\title{
CHARACTERIZATION AND NUTRIENT RELEASE FROM SILICATE ROCKS AND INFLUENCE ON CHEMICAL CHANGES IN SOIL ${ }^{(1)}$
}

\author{
Douglas Ramos Guelfi Silva(2), Giuliano Marchi( ${ }^{(3)}$, Carlos Roberto \\ Spehar ${ }^{(4)}$, Luiz Roberto Guimarães Guilherme ${ }^{(2)}$, Thomaz Adolpho \\ Rein $^{(3)}$, Danilo Araújo Soares ${ }^{(5)} \&$ Fabrício William Ávila ${ }^{(5)}$
}

\begin{abstract}
SUMMARY
The expansion of Brazilian agriculture has led to a heavy dependence on imported fertilizers to ensure the supply of the growing food demand. This fact has contributed to a growing interest in alternative nutrient sources, such as ground silicate rocks. It is necessary, however, to know the potential of nutrient release and changes these materials can cause in soils. The purpose of this study was to characterize six silicate rocks and evaluate their effects on the chemical properties of treated soil, assessed by chemical extractants after greenhouse incubation. The experimental design consisted of completely randomized plots, in a $3 \times 6$ factorial scheme, with four replications. The factors were potassium levels (0-control: without silicate rock application; $200 ; 400 ; 600 \mathrm{~kg} \mathrm{ha}^{-1}$ of $\mathrm{K}_{2} \mathrm{O}$ ), supplied as six silicate rock types (breccia, biotite schist, ultramafic rock, phlogopite schist and two types of mining waste). The chemical, physical and mineralogical properties of the alternative rock fertilizers were characterized. Treatments were applied to a dystrophic Red-Yellow Oxisol (Ferralsol), which was incubated for 100 days, at $70 \%(\mathrm{w} / \mathrm{w})$ moisture in $3.7 \mathrm{~kg} /$ pots. The soil was evaluated for $\mathrm{pH}$; calcium and magnesium were extracted with $\mathrm{KCl} 1 \mathrm{~mol} \mathrm{~L}^{-1}$; potassium, phosphorus and sodium by Mehlich 1; nickel, copper and zinc with DTPA; and the saturation of the cation exchange capacity was calculated for aluminum, calcium, magnesium, potassium, and sodium, and overall base saturation. The alternative fertilizers affected soil chemical properties. Ultramafic rock and Chapada mining byproduct (CMB) were the silicate rocks that most influenced
\end{abstract}

(1) Received for publication in June 29, 2011 and approved in April 12, 2012.

(2) Professor Soil Science Department, Federal University of Lavras - UFLA. CP 3037, CEP 37200-000 Lavras (MG), Brazil. E-mails: douglasguelfi@dcs.ufla.br; guilherm@dcs.ufla.br

(3) Research Embrapa Cerrados, Rodovia BR 020, Km 18, CEP 73370-970 Planaltina (DF), Brazil. E-mails: giuliano.marchi@cpac. embrapa.br; rein@cpac.embrapa.br

(4) Professor Faculty of Agronomy and Veterinary Medicine, University of Brasília, Campus Universitário Darcy Ribeiro, Asa Norte, CEP 70910-970 Brasília (DF), Brazil. E-mail: spehar@unb.br

(5) Student of the Doctorate Program on Soil Science at Universidade Federal de Lavras - UFLA. E-mails: daniloagro@ymail.com; avilafw@yahoo.com.br 
soil $\mathrm{pH}$, while the mining byproduct (MB) led to high $\mathrm{K}$ levels. Zinc availability was highest in the treatments with mining byproduct and $\mathrm{Cu}$ in soil fertilized with Chapada and mining byproduct.

Index terms: multi-nutrient fertilizer, nutrient available, potassic rock, rock powder, soil amendment.

\title{
RESUMO: CARACTERIZAÇÃOE LIBERAÇÃODE NUTRIENTES DE ROCHAS SILICÁTICAS E SUAS ALTERAÇÕES NOS ATRIBUTOS QUÍMICOS DO SOLO
}

\begin{abstract}
O crescimento da agricultura brasileira tem gerado aumento da importação de fertilizantes para atender à demanda por alimentos, aumentando os preços no mercado interno. Esse fato tem contribuido para aumento no interesse de utilização de fontes alternativas de nutrientes, como as rochas moídas e alguns subprodutos de agroindústria e mineração que podem se tornar um passivo ambiental. Contudo, faz-se necessário conhecer o potencial de liberação dos nutrientes, bem como as alterações no solo causadas por esses materiais. Este trabalho teve como objetivo caracterizar seis rochas silicáticas e avaliar os efeitos desses materiais nos atributos químicos do solo por meio de extratores químicos, em incubação realizada em casa de vegetação. O experimento foi conduzido no Departamento de Ciência do Solo da Universidade Federal de Lavras, utilizando as seguintes rochas silicáticas como tratamentos: brecha, ultramáfica, biotita xisto, flogopitito, subproduto de mineração e subproduto de Chapada, MS. Doses de rochas silicáticas, correspondendo a $0,200,400$ e $600 \mathrm{~kg} \mathrm{ha}^{-1}$ de $\mathrm{K}_{2} \mathrm{O}$ foram adicionadas a um Latossolo Vermelho Amarelo distrófico e incubadas por 100 dias. Em seguida, foram determinados os valores de $p H$ (água); Ca e $\mathrm{Mg}$, extraídos com $\mathrm{KCl} 1 \mathrm{~mol} \mathrm{~L}^{-1}$; K, P e Na, extraídos pelo Mehlich-1; Ni, $\mathrm{Cu}$ e Zn, extraídos por DTPA; saturação por alumínio (m); saturação da CTC potencial por cálcio, magnésio, potássio e sódio; e saturação por bases (V). As rochas moídas alteraram os atributos químicos do solo. Nas doses aplicadas, a ultramáfica e o subproduto de Chapada foram as rochas que mais influenciaram o $\mathrm{pH}$ do solo, enquanto o subproduto de mineração é o que disponibiliza mais K. Maior disponibilidade de Zn ocorreu com a aplicação do subproduto de mineração e de Cu quando se aplicaram subprodutos de Chapada e mineração.
\end{abstract}

Termos de indexação: correção do solo, disponibilidade de nutrientes, fertilizante multinutriente, pó de rocha, rocha potássica.

\section{INTRODUCTION}

The Brazilian production of potash salts covers only $8 \%$ of the country's requirements (Oliveira, 2008). The remainder has been imported from Canada, Russian Federation, Belarus and Germany. The increasing use of nutrients is a result of the rapid growth of high-technology and effective agriculture, especially in savanna regions (ANDA, 2011). The world-wide demand has caused considerable price rises of conventional fertilizer sources, affecting the agricultural development, especially in tropical countries (Manning, 2010).

To face this constraint, nutrient-rich rocks can be ground and used to reduce the dependence on imported sources. The technique consists of applying rock powder directly onto the soils; the competitiveness of this practice is directly related to the nutrient contents of the material and to the distance from the mining areas. These rocks might vary in quantity and sources of mineral elements they contain, but contribute to raise soil fertility, in the mid-to-long term, depending on the solubility and reaction with soil (Hilsinger et al., 1996; van Straaten, 2007). Rocks and their byproducts are, in general, sources of phosphorus $(\mathrm{P})$, potassium, calcium $(\mathrm{Ca})$ and magnesium $(\mathrm{Mg})$, often including trace-elements, such as zinc $(\mathrm{Zn})$ and copper $(\mathrm{Cu})$, which are essential in plant nutrition (Leonardos et al., 1991, 2000; Wilpert \& Lukes, 2003; Leonardos \& Theodoro, 1999; Theodoro \& Leonardos, 2006; Fyfe et al., 2006). 
The breccia, biotite schist, ultramafic rock, mining byproducts, and phlogopite schist rock powder and mining wastes were selected for their levels of $\mathrm{K}$, micronutrients and $\mathrm{Na}$. When applied to soils, they become a major $\mathrm{K}$ source, even though feldspar-rich rocks have shown to be more efficient in raising $\mathrm{K}$ availability (Resende et al., 2006; Manning, 2010). These alternative fertilizers may however bring other undesirable elements into the soil, e.g., sodium $(\mathrm{Na})$ and, if applied at high quantities, alter the soil $\mathrm{pH}$. After their chemical reaction with soils, changes in $\mathrm{pH}$ occur, contributing to mineral imbalance and availability of toxic elements (Moreira et al., 2006). Other studies have been conducted with basalt powder (microcrystalline basalt and olivinebasalt), carbonatite, pyroclastic rock, biotite schist, and alkaline ultramafic rock, carbonatite, adularia, showing increases in soil $\mathrm{K}$ levels (Escosteguy \& Klant 1998; Bakken et al., 2000; Andrade, 2002; Oliveira et al., 2006; Nogueira et al., 2012).

The origin and composition of rocks are factors that influence $\mathrm{K}$ solubility and, as a consequence, $\mathrm{K}$ availability to plants. These factors are, in turn, related to previous thermal- or chemical rock treatments, soil characteristics, incubation time, plant species being grown and synergetic action of microorganisms, such as bacteria (Harley \& Gilkes, 2000; Wang et al., 2000; Stanford et al., 2008).

Given the scarcity of information and procedures to compare rocks and byproducts with respect to solubility, soil property interferences, nutrient availability and plant uptake, further research is needed to assess their potential as fertilizers. The purpose of this study was to characterize six silicate rocks and evaluate their effects on the chemical properties of treated soil, assessed by chemical extractants after greenhouse incubation.

\section{MATERIAL AND METHODS}

Soil of a sandy-clay loam, dystrophic Red-Yellow Oxisol (Ferralsol) was sampled in Itutinga, MG, Brazil, under native savannah vegetation, in the 0-20 cm layer. The following physic-chemical characteristics were determined by soil analysis: $\mathrm{pH}$ (water) $=5.4 ; \mathrm{OM}=0.8 \mathrm{dag} \mathrm{kg} ; \mathrm{K}^{+}=22 \mathrm{mg} \mathrm{dm}^{-3}$; $\mathrm{S}=5.4 \mathrm{mg} \mathrm{dm}^{-3} ; \mathrm{P}=0.9 \mathrm{mg} \mathrm{dm}{ }^{-3} ; \mathrm{Ca}^{2+}=0.1 \mathrm{cmol}_{\mathrm{c}} \mathrm{dm}^{-3}$; $\mathrm{Mg}^{2+}=0.1 \mathrm{cmol}_{\mathrm{c}} \mathrm{dm}^{-3} ; \mathrm{Al}^{3+}=0.1 \mathrm{cmol}_{\mathrm{c}} \mathrm{dm}^{-3} ;(\mathrm{H}+\mathrm{Al})$ $=1.7 \mathrm{cmol}_{\mathrm{c}} \mathrm{dm}^{-3} ; \mathrm{SB}=0.3 \mathrm{cmol}_{\mathrm{c}} \mathrm{dm}^{-3} ; \mathrm{CEC}=$ $0.4 \mathrm{cmol}_{\mathrm{c}} \mathrm{dm}^{-3} ; \mathrm{CEC}$ at pH $7.0=2.0 \mathrm{cmol}_{\mathrm{c}} \mathrm{dm}^{-3} ; \mathrm{Fe}=$ $27.4 \mathrm{mg} \mathrm{dm}^{-3} ; \mathrm{Zn}=0.5 \mathrm{mg} \mathrm{dm}^{-3} ; \mathrm{Cu}=0.7 \mathrm{mg} \mathrm{dm}^{-3} ; \mathrm{B}$ $=0.0 \mathrm{mg} \mathrm{dm}^{-3} ; \mathrm{Mn}=0.4 \mathrm{mg} \mathrm{dm}^{-3}$; sand $=600 \mathrm{~g} \mathrm{~kg}^{-1}$; silt $=170 \mathrm{~g} \mathrm{~kg}^{-1}$; clay $=230 \mathrm{~g} \mathrm{~kg}^{-1}$. The extractors were: $\mathrm{KCl} 1 \mathrm{~mol} \mathrm{~L}^{-1}$ for $\mathrm{Ca}^{2+}, \mathrm{Mg}$ and $\mathrm{Al}$; Mehlich - 1 for K, P and Na; DTPA for $\mathrm{Ni}, \mathrm{Cu}$ and $\mathrm{Zn}$.

The treatments were applied to the dried and homogenized soil, which was filled into $3.7 \mathrm{~L}$ pots and placed in a glasshouse of the Soil Science Department, Federal University of Lavras (UFLA). The experimental design consisted of completely randomized plots, in a $3 \times 6$ factorial scheme, with four replications. The factors were $\mathrm{K}$ levels (0-control: without silicate rock application; 200; $400 ; 600 \mathrm{~kg} \mathrm{ha}^{-1}$ of $\mathrm{K}_{2} \mathrm{O}$ ), supplied as six alternative fertilizer rocks (breccia, biotite schist, ultramafic rock, Chapada mining byproduct and phlogopite schist). The amount of ground rock was defined on the basis of respective potassium oxide $\left(\mathrm{K}_{2} \mathrm{O}\right)$ concentration (Table 1).

Each experimental unit, a pot containing rocktreated soil, was randomly placed on a bench in a glasshouse and incubated for 100 days. Moisture in the pots was maintained at $70 \%(\mathrm{w} / \mathrm{w})$ at a mean temperature of $25{ }^{\circ} \mathrm{C}$. The ground mining wastes were applied in their original sieving as provided by

Table 1. Total content of $\mathrm{K}_{2} \mathrm{O}^{(1)}, \mathrm{Na}_{2} \mathrm{O}^{(1)}, \mathrm{P}_{2} \mathrm{O}_{5}^{(1)}, \mathrm{CaO}^{(1)}, \mathrm{MgO}^{(1)}, \mathrm{Cu}^{(2)}, \mathrm{Zn}^{(2)}$, and $\mathrm{Ni}^{(2)}$ of ground rocks and mining waste

\begin{tabular}{|c|c|c|c|c|c|c|c|c|}
\hline $\begin{array}{l}\text { Silicate rocks and } \\
\text { mining waste }\end{array}$ & $\mathrm{K}_{2} \mathrm{O}$ & $\mathrm{Na}_{2} \mathrm{O}$ & $\mathbf{P}_{2} \mathbf{O}_{5}$ & $\mathrm{CaO}$ & MgO & $\mathrm{Cu}$ & $\mathrm{Zn}$ & $\mathrm{Ni}$ \\
\hline & & & $-\%$ & 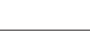 & - & 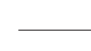 & - $\mathrm{mg} \mathrm{kg}^{-1}$ & - \\
\hline Breccia & 2.18 & 0.31 & 0.94 & 9.03 & 7.09 & 59.9 & 128.7 & 73.9 \\
\hline \multirow{3}{*}{$\begin{array}{l}\text { Ultramafic rock } \\
\text { Chapada mining } \\
\text { byproduct } \\
\text { Mining byproduct }\end{array}$} & 3.10 & 1.71 & 1.22 & 13.00 & 18.50 & 87.4 & 113.1 & 651.9 \\
\hline & 3.39 & 1.62 & 0.19 & 3.19 & 3.88 & 437.5 & 123.0 & 2.8 \\
\hline & 11.80 & 0.72 & 0.42 & 3.58 & 0.70 & 816.8 & $28,184.2$ & 380.3 \\
\hline Biotite schist & 2.07 & 0.86 & 0.06 & 5.27 & 13.8 & 9.9 & 290.5 & 146.4 \\
\hline Phlogopite schist & 7.71 & 0.16 & 0.20 & 0.98 & 22.89 & 9.1 & 902.7 & $1,425.2$ \\
\hline
\end{tabular}

(1) Methods 4A \& 4B by Acmelabs (Canada): Prepared sample is mixed with $\mathrm{LiBO}_{2} / \mathrm{Li}_{2} \mathrm{~B}_{4} \mathrm{O}_{7}$ flux. Crucibles are fused in a furnace. The cooled bead is dissolved in ACS grade nitric acid. Loss on ignition (LOI) is determined by the weight loss of an ignited split sample. ${ }^{(2)}$ Method 3052 USEPA (1996). 
the suppliers (Table 2). This is possibly the form to be used by farmers, with no additional preparation cost, as has been defined for lime.
Photomicrographs of rocks were taken with a camera attached to a petrographic microscope (Figure 1).

Table 2. Granulometry of ground rocks and mining wastes used in the experiment

\begin{tabular}{|c|c|c|c|c|c|}
\hline \multirow{2}{*}{ Silicate rocks } & \multicolumn{5}{|c|}{ Particle-size distribution } \\
\hline & $1 \mathrm{~mm}$ & $0.42 \mathrm{~mm}$ & $0.250 \mathrm{~mm}$ & $0.125 \mathrm{~mm}$ & $<0.125 \mathrm{~mm}$ \\
\hline & \multicolumn{5}{|c|}{$-\%$} \\
\hline Breccia & 32.85 & 31.69 & 9.28 & 22.01 & 4.17 \\
\hline Ultramafic rock & 22.14 & 20.84 & 14.29 & 22.29 & 20.44 \\
\hline Chapada Mining Byproduct & 21.13 & 23.75 & 13.85 & 22.64 & 18.63 \\
\hline Mining Byproduct & 26.58 & 28.34 & 8.60 & 32.42 & 4.06 \\
\hline Biotite schist & 9.88 & 30.14 & 25.02 & 23.36 & 11.60 \\
\hline Phlogopite schist & 11.55 & 27.43 & 35.76 & 13.62 & 11.64 \\
\hline
\end{tabular}

(a)

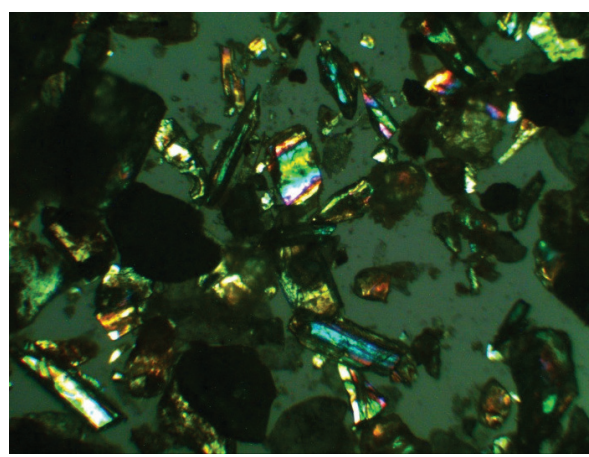

(c)

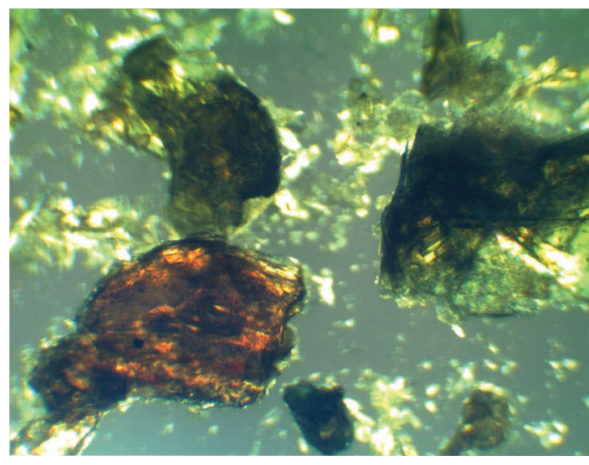

(e)

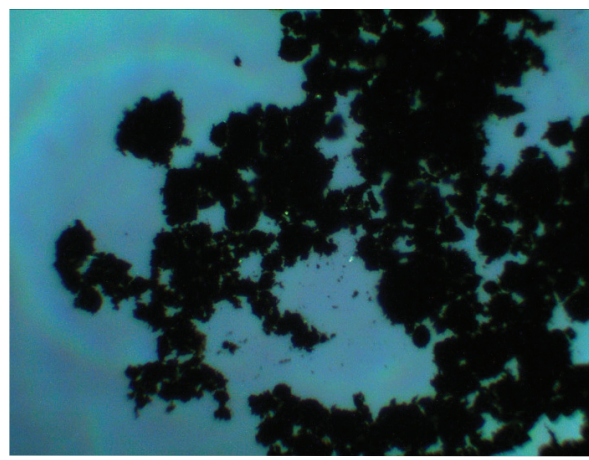

(b)

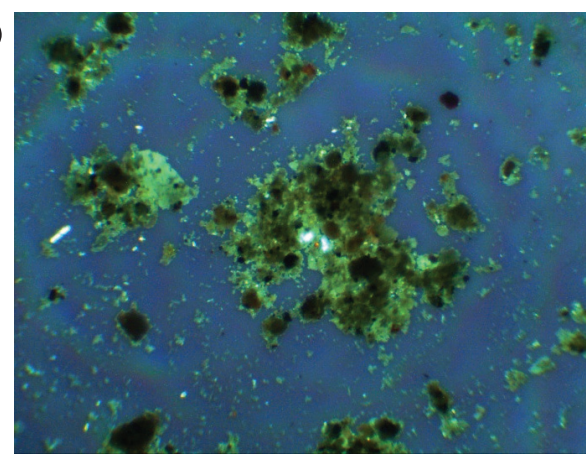

(d)

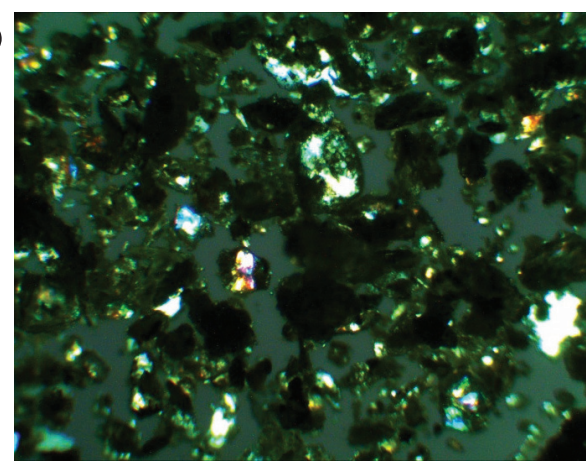

(f)

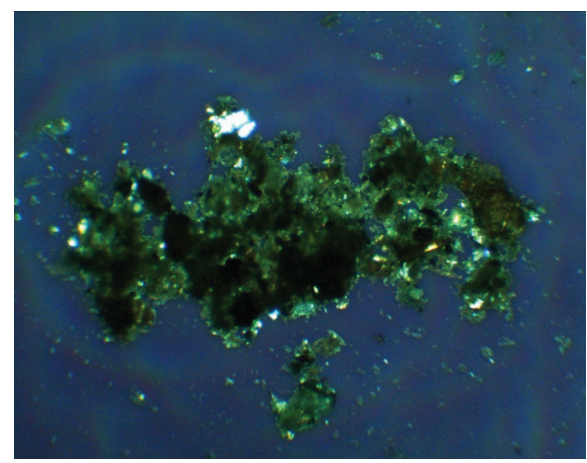

Figure 1. Photomicrography (XPL) of biote schist (a), breccia (b), phlogopite schist (c), Chapada mining byproduct (CMB) (d), mining byproduct (MB) (e) and ultramafic rock (f). Picture width corresponding to $2.3 \mathrm{~mm}$. 
The ground rock treatments, for which the respective $\mathrm{K}$ contents were calculated, carry traceelements in variable quantities (Table 3).

The soil and rocks were analyzed by X-Ray diffractometry with a vertical goniometer and $\theta$ geometry for mineralogical fraction determination. The equipment was adjusted at an angular variation of $2-100^{\circ}(2 \theta)$, radiation of $\mathrm{CuK} \alpha(\mathrm{l}=1.5450)$ and speed of $1^{\circ} 2 \theta \mathrm{min}^{-1}$ (Bigham et al., 2001; Azzone \& Ruberti, 2010).

After the incubation period, soil samples were collected for analysis of $\mathrm{pH}\left(\mathrm{H}_{2} \mathrm{O}\right), \mathrm{Ca}, \mathrm{Mg}, \mathrm{K}, \mathrm{P}, \mathrm{Na}$, $\mathrm{Ni}, \mathrm{Cu}$, and $\mathrm{Zn}$, following the previous procedure for soil analysis, to assess soil reactions to the treatments. The $\mathrm{Al}$ saturation rate $(\mathrm{m})$, cation saturation $(\mathrm{Ca}, \mathrm{Mg}, \mathrm{K}$ and $\mathrm{Na})$ of potential cation exchange capacity (CEC at $\mathrm{pH}$ 7.0) and soil base saturation rate were calculated.

The data were subjected to analysis of variance and the means compared by the Tukey test $(p=$ 0.05), using the statistical package SISVAR $5.3^{\circledR}$ (Ferreira, 2008). The rate effect and interactions were compared by regression analysis, using mathematical models for best fit equation.

\section{RESULTS AND DISCUSSION}

The $\mathrm{K}$ rates, ground rock types, and the respective interactions influenced $(p=0.05)$ the nutrient availability and some soil chemical properties (Figure 2). In general, the $\mathrm{pH}$ values increased proportionally to the rate of ground rock and were related to the type of nutrient sources. Ultramafic rock and mining byproducts resulted in considerable soil $\mathrm{pH}$ rises, as a result of the amount and neutralizing power of rock. Moreover, the CEC of the Red-Yellow Oxisol (Ferralsol) was low, and was little buffered by acidity- neutralizing minerals (Souza et al., 2011).

Other glasshouse studies with ultramafic rock and phlogopite schist, from the States of Goiás, Santa Catarina and Bahia, Brazil, all with particles $>0.3 \mathrm{~mm}$, also reported changes in $\mathrm{pH}$ (Ribeiro et al., 2010), similar to the Oxisol studied. Moreover, in a typical savannah, clayey dystrophic Red Oxisol, the $\mathrm{pH}$ and potential acidity were altered by breccia, ultramafic rock and biotite schist rock powder.

The variations in $\mathrm{pH}$ can also be explained by the different values of effective calcium carbonate (ECC) (Table 4). In the case of biotite schist, breccia and phlogopite schist, the ECC values are very low, with less effect on $\mathrm{pH}$ changes. It should be emphasized that none of these mining wastes is specifically indicated for use as soil amendment, to regulate soil acidity and increase $\mathrm{Ca}$ and $\mathrm{Mg}$ supply (Brazilian regulations require a minimum $\mathrm{CCE}=67 \%$; minimum $\mathrm{CaO}+\mathrm{MgO}=38 \%$; Total $\mathrm{ECC}=45 \%)$.

Calcium availability and saturation increased with the rate of rock powder and were related to the type of nutrient sources (Figure 2b,c). Prior to the addition of rocks and mining wastes, $\mathrm{Ca}^{2+}$ availability was very low $\left(0.1 \mathrm{cmol}_{\mathrm{c}} \mathrm{dm}^{-3}\right)$ in native soil, whereas after incubation for 100 days, $\mathrm{Ca}^{2+}$ increased in all treatments. Calcium soil content was in the range of "very low availability" (0.1 $\mathrm{cmol}_{\mathrm{c}} \mathrm{dm}^{-3}$; CFSEMG, 1999) before the application of ground rocks, and after incubation of 100 days, only the soil treated with ultramafic rock reached the range of "low availability".

A CEC of $40-60 \%$ saturated by $\mathrm{Ca}^{2+}$ is most suitable for Oxisols (Lopes, 1998). Even though none of the rock treatments reached this level, the data showed that the ground rocks and mining

Table 3. Origin ${ }^{(1)}$ of ground rocks and mining wastes with respective rate and available trace-elements ${ }^{(2)}$

\begin{tabular}{|c|c|c|c|c|c|c|c|c|c|c|c|c|c|}
\hline \multirow{2}{*}{$\begin{array}{l}\text { Silicate rocks } \\
\text { and mining } \\
\text { waste }\end{array}$} & \multirow{2}{*}{$\begin{array}{c}\text { Location in } \\
\text { Brazil }\end{array}$} & \multicolumn{4}{|c|}{$200 \mathrm{~kg} \mathrm{ha}^{-1}$ of $\mathrm{K}_{2} \mathrm{O}$} & \multicolumn{4}{|c|}{$400 \mathrm{~kg} \mathrm{ha}^{-1}$ of $\mathrm{K}_{2} \mathrm{O}$} & \multicolumn{4}{|c|}{$600 \mathrm{~kg} \mathrm{ha}^{-1}$ of $\mathrm{K}_{2} \mathrm{O}$} \\
\hline & & Total ${ }^{(3)}$ & $\mathrm{Ni}$ & $\mathrm{Cu}$ & $\mathrm{Zn}$ & Total & $\mathrm{Ni}$ & $\mathrm{Cu}$ & $\mathrm{Zn}$ & Total & $\mathrm{Ni}$ & $\mathrm{Cu}$ & $\mathrm{Zn}$ \\
\hline & & $\mathrm{t} \mathrm{ha}^{-1}$ & & $\mathrm{mg} \mathrm{kg}^{-1}$ & & $\mathrm{t} \mathrm{ha}^{-1}$ & & $\mathrm{mg} \mathrm{kg}^{-1}$ & & $\mathrm{t} \mathrm{ha}^{-1}$ & & $\mathrm{mg} \mathrm{kg}^{-1}$ & \\
\hline \multirow{4}{*}{$\begin{array}{l}\text { Breccia } \\
\text { Ultramafic rock } \\
\text { Chapada Mining } \\
\text { Byproduct } \\
\text { Mining Byproduct }\end{array}$} & Rio Verde - GO & 20.45 & 0.41 & 0.33 & 0.71 & 40.91 & 0.82 & 0.66 & 1.42 & 61.36 & 1.22 & 0.99 & 2.13 \\
\hline & Lages - SC & 14.38 & 2.53 & 0.34 & 0.44 & 28.77 & 5.06 & 0.68 & 0.88 & 43.15 & 7.60 & 1.02 & 1.3 \\
\hline & Chapada -GO & 13.15 & 0.01 & 1.55 & 0.44 & 26.31 & 0.02 & 3.11 & 0.87 & 39.46 & 0.03 & 4.66 & 1.31 \\
\hline & Sete Lagos -MG & 78 & 0.39 & 0.84 & 28.79 & 7.56 & 0.78 & 1.67 & 57.58 & 11.34 & 1.17 & 2.51 & 86.38 \\
\hline \multirow{2}{*}{$\begin{array}{l}\text { Biotite schist } \\
\text { Phlogopite schist }\end{array}$} & Nova Era - MG & 24.54 & 0.97 & 0.06 & 1.93 & 43.08 & 1.94 & 0.13 & 3.85 & 64.62 & 2.91 & 0.19 & 5.78 \\
\hline & $\begin{array}{l}\text { Campo Formoso } \\
\text {-BA }\end{array}$ & 5.78 & 2.23 & 0.001 & 1.41 & 11.56 & 4.45 & 0.003 & 2.82 & 17.34 & 6.68 & 0.004 & 4.23 \\
\hline
\end{tabular}

(1) Origin of the rocks according to Resende et al. (2006). (2) Soil bulk density: $1.0 \mathrm{Mg} \mathrm{m}^{-3}$. (3) Rate total of silicate rocks. 

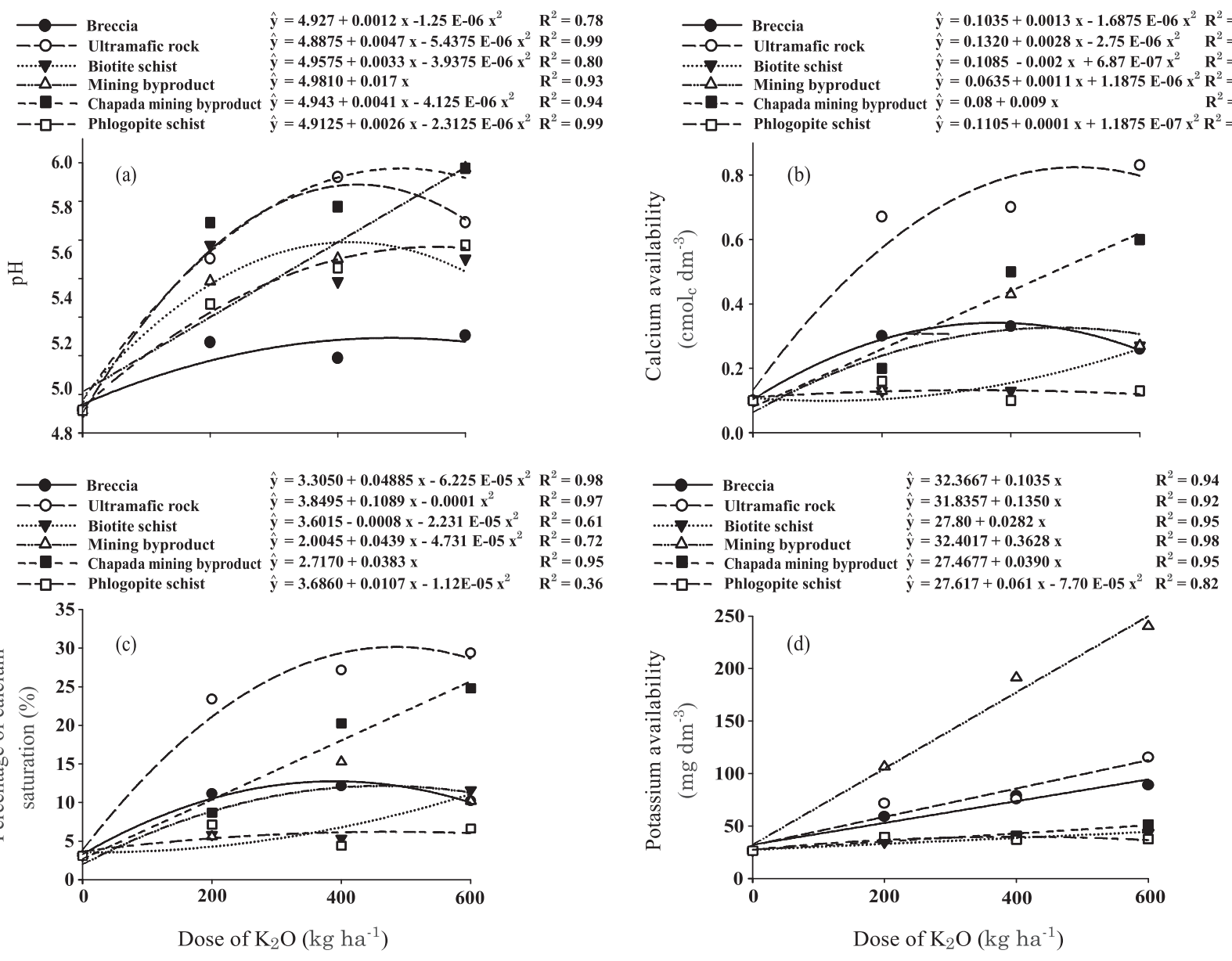

Figure 2. Soil pH (a), Ca availability (b), Ca saturation (c), K availability (d) for breccia, ultramafic rock, biotite schist, mining byproduct, Chapada mining byproduct and phlogopite schist.

Table 4. $\mathrm{pH}\left(\mathrm{H}_{2} \mathrm{O}\right)$ of silicate rocks ${ }^{(1)}$, soluble $\mathrm{CaO}, \mathrm{MgO}$, calcium carbonate equivalent (CCE), fitness factor (FF), calcium and magnesium fitness factor and effective calcium carbonate (ECC) of the rocks and mining wastes ${ }^{(2)}$

\begin{tabular}{|c|c|c|c|c|c|c|c|c|}
\hline Silicate rocks and mining waste & $\mathrm{pH} \mathrm{H}_{2} \mathrm{O}$ & $\mathrm{CaO}$ & MgO & CCE & FF & ECC & $\mathbf{C a}$ & $\mathrm{Mg}$ \\
\hline & & \multicolumn{7}{|c|}{ dag $\mathrm{kg}^{-1}$} \\
\hline Breccia & 8.3 & 2.23 & 1.34 & 4.78 & 71.20 & 3.41 & 1.59 & 0.80 \\
\hline Ultramafic rock & 9.4 & 10.84 & 8.95 & 39.47 & 71.24 & 28.12 & 7.74 & 5.39 \\
\hline Chapada mining byproduct & 7.6 & 2.07 & 1.62 & 5.99 & 98,32 & 5.89 & 1.48 & 0.97 \\
\hline Mining byproduct & 10.8 & 2.73 & 0.55 & 11.29 & 87.92 & 9.92 & 1.95 & 0.33 \\
\hline Biotite schist & 8.2 & 0.07 & 1.45 & 1.65 & 68.40 & 1.13 & 0.05 & 0.84 \\
\hline Phlogopite schist & 8.5 & 0.13 & 0.57 & 0.45 & 82.32 & 0.37 & 0.09 & 0.34 \\
\hline
\end{tabular}

(1) Moreira et al. (2006). (2) Brasil (2007).

wastes under study, at high rates, released $\mathrm{Ca}^{2+}$ in addition to $\mathrm{K}^{+}$, creating conditions to ameliorate soil acidity.

The $\mathrm{Ca}^{2+}$ increase is related to clay-mineral 2:1 (Chapada mining byproduct), pyroxene and feldspar, present in ultramafic rock and breccia powder
(Figure 3). The differences between pyroxene and feldspar, in terms of nutrient release, have been compared and reviewed, confirming the dynamics observed in this experiment (Hilsinger et al., 1996; Manning, 2010). Pyroxenes are altered in their constitution when placed in soils in powder form, releasing $\mathrm{Ca}^{2+}, \mathrm{Mg}^{2+}$ and $\mathrm{Fe}^{2+}$, while feldspars can 
be potassic $\left(\mathrm{KAlSiO}_{3}\right)$ or calco-sodic $\left(\mathrm{NaAlSi}_{3} \mathrm{O}_{8}\right.$ and $\mathrm{CaAl}_{2} \mathrm{Si}_{2} \mathrm{O}_{8}$ ); in reaction with soil, they release $\mathrm{K}^{+}$, $\mathrm{Ca}^{2+}$ and $\mathrm{Mg}^{2+}$ (Brady \& Weil 2002; Meurer, 2006; Resende et al., 2007). This increases the relative availability of these elements in soil.

X-Ray diffractograms of soil and rock powder indicate the presence of phlogopite schist $\left(\mathrm{KMg}_{3}\left(\mathrm{AlSi}_{3} \mathrm{O}_{10}\right)(\mathrm{F}, \mathrm{OH})_{2}\right)$ and talc $\left(\mathrm{Mg}_{3} \mathrm{Si}_{4} \mathrm{O}_{10}(\mathrm{OH})_{2}\right)$ in phlogopite schist. Phlogopite schist belongs to the group of micas, $2: 1$ phyllosilicate (tetrahedronoctrahedron-tetrahedron), with a layer of nonhydrated cations, offsetting the excess negative charges in the layers (Deer et al., 1962; Azzone \& Ruberti, 2010).

In the Chapada mining byproduct, the presence of 2:1 clay-mineral, quartz $\left(\mathrm{SiO}_{2}\right)$ and rutile $\left(\mathrm{TiO}_{2}\right)$ was detected, while in biotite schist, of the phyillosilicate group, biotite and mica were present. This is a possible cause for the release of $\mathrm{K}^{+}, \mathrm{Ca}^{2+}$, and $\mathrm{Mg}^{2+}$ from rock to soil. For the mining byproducts, these data were not obtained due to the interference of low cristallinity material in the samples.

The main compounds in ultramafic rock were $2: 1$ clay-minerals and olivine $(\mathrm{Mg}, \mathrm{Fe})_{2} \mathrm{SiO}_{4}$, pyroxene and feldspar. The latter is a neosilicate, common in igneous and metamorphic rocks, pyroxenes of single-chain inosilicate and in feldspar.

The mineralogy of ground rocks utilized as fertilizers is diversified, underlying the differential nutrient release by the soil reactions. The $\mathrm{K}^{+}$soil levels and CEC saturation by the element increased after incubation for 100 days (Figures $2 \mathrm{~d}$ and $4 \mathrm{a}$ ). As expected, $\mathrm{K}^{+}$soil levels increased proportionally to the applied amounts and $\mathrm{K}$ was released from the following fertilizers (descending order): mining byproduct $>$ ultramafic rock $=$ breccia $>$ Chapada mining byproduct $=$ biotite schist $=$ phlogopite schist.

Exchangeable $\mathrm{K}^{+}$in pristine soil was $22 \mathrm{mg} \mathrm{dm}^{-3}$, close to the minimum for plant growth "low" (16-40 $\mathrm{mg} \mathrm{dm}^{-3}$ ) (CFSEMG, 1999). After the application of phlogopite schist $\left(39.7 \mathrm{mg} \mathrm{dm}^{-3}\right)$ and mining byproduct $\left(37.7 \mathrm{mg} \mathrm{dm}^{-3}\right)$ at the rate of $200 \mathrm{~kg} \mathrm{ha}^{-1}$ of $\mathrm{K}_{2} \mathrm{O}$ and biotite, at $200\left(34.7 \mathrm{mg} \mathrm{dm}^{-3}\right)$ and $400 \mathrm{~kg} \mathrm{ha}^{-1}\left(40 \mathrm{mg} \mathrm{dm}^{-3}\right)$ the $\mathrm{K}^{+}$content remained low. Breccia $\left(200 \mathrm{~kg} \mathrm{ha}^{-1} \mathrm{~K}_{2} \mathrm{O}\right)$, biotite schist (400 and $600 \mathrm{~kg} \mathrm{ha}^{-1} \mathrm{~K}_{2} \mathrm{O}$ ) and Chapada mining byproduct ( 400 and $600 \mathrm{~kg} \mathrm{ha}^{-1} \mathrm{~K}_{2} \mathrm{O}$ ) raised the level to "medium" (41-70 $\mathrm{mg} \mathrm{dm}^{-3}$ ) and applications of breccia (400 and $600 \mathrm{~kg} \mathrm{ha}^{-1} \mathrm{~K}_{2} \mathrm{O}$ ), ultramafic rock (200, 400 and $600 \mathrm{~kg} \mathrm{ha}^{-1} \mathrm{~K}_{2} \mathrm{O}$ ), mining byproduct $\left(200 \mathrm{~kg} \mathrm{~K}_{2} \mathrm{O} \mathrm{ha}^{-1}\right)$ led to "high" (71-120 $\left.\mathrm{mg} \mathrm{dm}^{-3}\right) \mathrm{K}^{+}$ levels. Mining byproduct at rates of $400 \mathrm{~kg} \mathrm{ha}^{-1} \mathrm{~K}_{2} \mathrm{O}$ $\left(191 \mathrm{mg} \mathrm{dm}^{-3}\right)$ and $600 \mathrm{~kg} \mathrm{ha}^{-1} \mathrm{~K}_{2} \mathrm{O}\left(240 \mathrm{mg} \mathrm{dm}^{-3}\right)$ resulted in high $\left(>120 \mathrm{mg} \mathrm{dm}^{-3}\right)$ available $\mathrm{K}^{+}$in soil.

The types of minerals, the $\mathrm{K}^{+}$arrangement in the rock mineral structure, the particle-size distribution (100\% $0.150 \mathrm{~mm}$ and $45 \%<0.075 \mathrm{~mm}$ mesh to assure total reactivity) and possible action of synergetic microorganisms can hamper $\mathrm{K}^{+}$release from rocks (Wang et al., 2000; Moreira et al., 2006; Stanford et al., 2008).

The most important minerals detected in the rock powder, which are potential $\mathrm{K}$ sources to soils, were phlogopite schist (phlogopite schist); illite and biotite; feldspars (ultramafic rock), feldspars and phlogopite schist (breccia) (Figure 3).

With the exception of the mining waste, the feldspar-containing rocks led to high $\mathrm{K}$ availability (ultramafic rock and breccia). The $\mathrm{K}$ they released was not readily exchangeable, due to strong binding to $\mathrm{SiO}_{4}$ and $\mathrm{AlO}_{4}$ tetrahedron, compensating charge deficiency in mineral structure. The final K release into soil depends on cation exchange in acid medium as follows: $\mathrm{K} \mathrm{AlSi}_{3} \mathrm{O}_{8}+\mathrm{H}^{+} \rightarrow \mathrm{HAlSiO}_{8}+\mathrm{K}^{+}$(Curi et al., 2005).

In breech mineral phase, phlogopite schist and feldspars were found; the latter are tectosilicates and rather important nutrient sources when altered they supply $\mathrm{K}^{+}$and $\mathrm{Ca}^{2+} \mathrm{Na}^{+}$and $\mathrm{Fe}^{2+}$ (Meurer, 2006; Resende et al., 2007).

In the case of biotite schist and phlogopite schist, the main potassium sources were illite, biotite (dark mica) and phlogopite schist. Mica layers, consisting of tetra- and octahedral components, retain $\mathrm{K}^{+}$in the space in-between, strongly bound by oxygen molecules. This binding hinders layer expansion, causing low $\mathrm{K}^{+}$release into the soil. From biotite and phlogopite schist, with tri-octahedral blades components, $\mathrm{K}$ tends to be released faster than from muscovite (Curi et al., 2005).

In the tri-octahedral mica-type structure, the $\mathrm{K}-\mathrm{O}$ binding is longer $(0.3 \mathrm{~nm})$ than in the dioctahedral $(0.285 \mathrm{~mm})$, making the binding to the first weaker. In addition, the mica-type structure has a repulsion force caused by octahedral $\mathrm{Al}^{3+}$ over $\mathrm{H}^{+}$from oxydril that diverts $\mathrm{H}$ in the octahedron direction, driving $\mathrm{K}$ farther away (Brown et al., 1978). Consequently, repulsion and binding forces are weaker in the proximity of $\mathrm{H}$ and $\mathrm{K}$ ions in trioctahedral than in di-octahedral micas (Bigham et al., 2001; Brady \& Weil, 2002; Wilson, 2004; Curi et al., 2005).

Potassium saturation of potential CEC varied between 3.9 and $23.7 \%$ (Figure $4 \mathrm{a}$ ). The adequate value for this characteristic is between 2 and $5 \%$ (Lopes, 1998), according to field crop requirements. Although CEC is highly occupied by $\mathrm{K}^{+}$, the studied soil had a very low CEC $\left(2.0 \mathrm{cmol}_{\mathrm{c}} \mathrm{dm}^{-3}\right)$, meaning that even a small amount of $\mathrm{K}^{+}$can occupy a great extent of the exchangeable sites. 


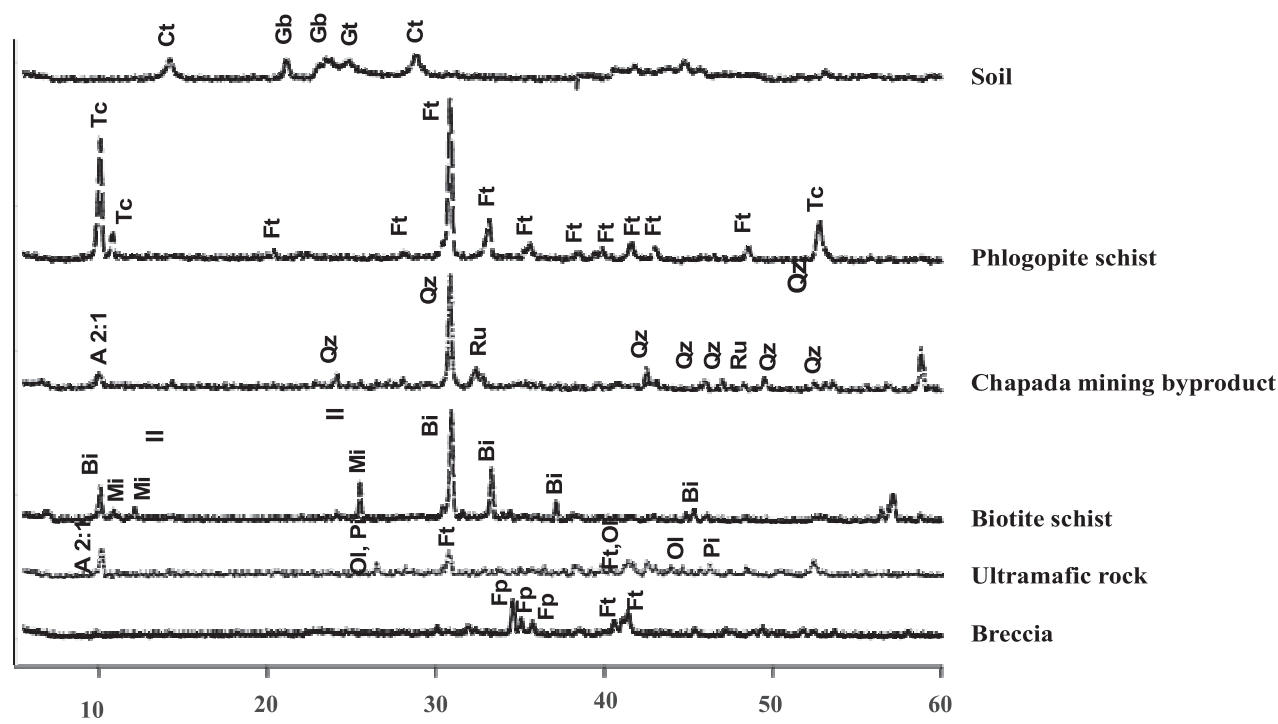

Figure 3. X-ray diffractograms of soil and ground rocks, utilized as fertilizers. Ct: Kaolinite; Gb: Gibbsite; Gt: Goethite; Tc: Talc; Ft: Phlogopite schist; A 2:1: Clay-mineral 2:1; Qz: Quartz; Ru: Rutile; Bi: Biotite; Il:Illite; Ol: Olivine; Pi: Pyroxene; Fp: Feldspar.
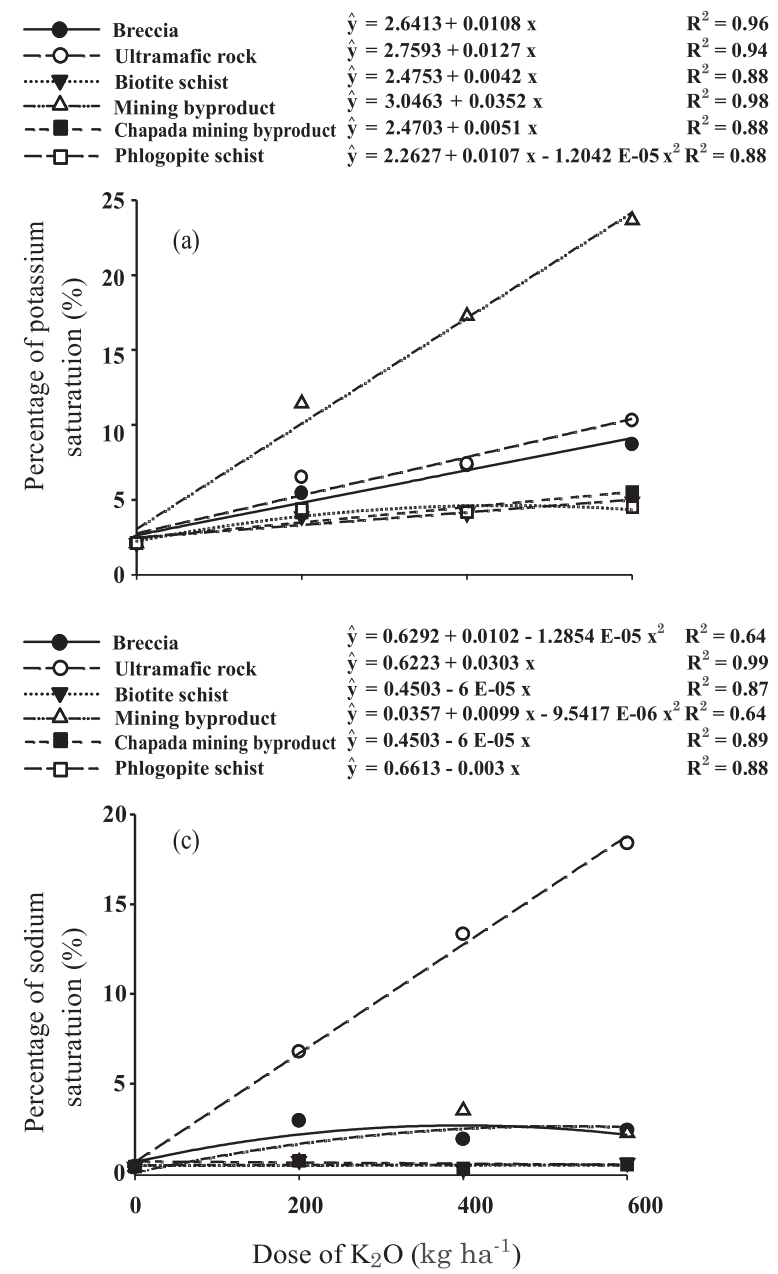
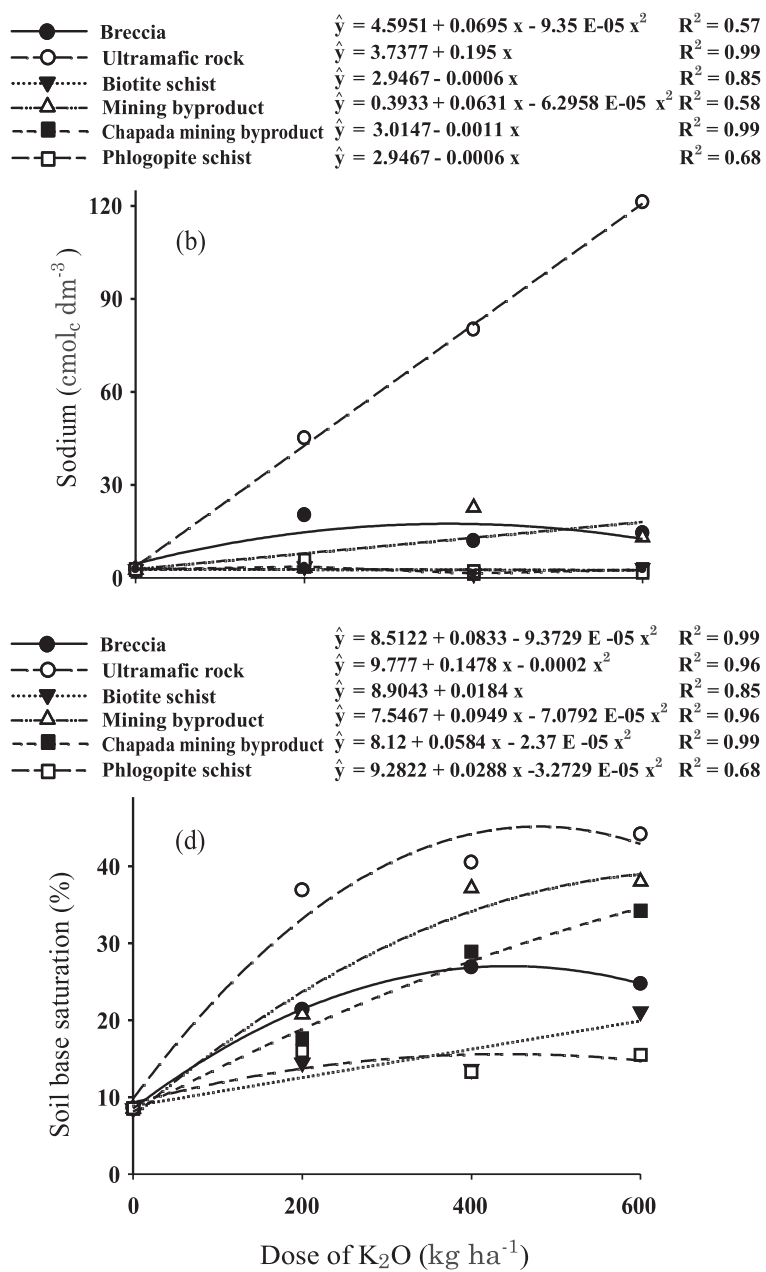

Figure 4. Potassium saturation (a), sodium availability (b), sodium saturation (c) and base saturation (d) of soil fertilized by breccia, ultramafic rock, biotite schist, mining byproduct, Chapada mining byproduct and phlogopite schist. 
Ultramafic rock also increased the $\mathrm{Na}^{+}$soil levels considerably, with a maximum of $121.13 \mathrm{mg} \mathrm{dm}^{-3}$, followed by breccia and mining byproduct, with 20.23 and $13.20 \mathrm{mg} \mathrm{dm}^{-3}$, respectively (Figure $4 \mathrm{~b}, \mathrm{c}$ ). The high sodium availability induced by ultramafic rock was reflected in the $\mathrm{CEC}$ saturation, reaching a maximum of $18.4 \%$ at $600 \mathrm{~kg} \mathrm{ha}^{-1} \mathrm{~K}_{2} \mathrm{O}$.

The high $\mathrm{Na}^{+}$levels resulting from the ultramafic rock treatments can be explained by release from Na-rich minerals present in these rocks, such as plagioclase feldspars $\left(\mathrm{NaAlSiO}_{3}\right)$, from which the element becomes available in soil (Meurer, 2006).

Sodium saturation rates of $15 \%$ and higher may affect some of the physical properties of soils, among them hydraulic conductivity (Richards, 1954). This happens because $\mathrm{Na}^{+}$increases the diffuse double layer, promoting colloid dispersion and movement, obstructing pores, thus altering conductivity, water movement, aeration and fertility in soils. Therefore, the $\mathrm{Na}$ level in rocks must be taken into consideration before using them as fertilizers.

The increased availability of $\mathrm{Ca}^{2+}, \mathrm{Mg}^{2+}, \mathrm{K}^{+}$and $\mathrm{Na}^{+}$changed the base saturation in soils (Figure 4d), proportional to the application rates, except for phlogopite schist. Highest values were obtained by applications of ultramafic rock, mining byproduct and mining byproduct, confirming the liming effect of these fertilizers.

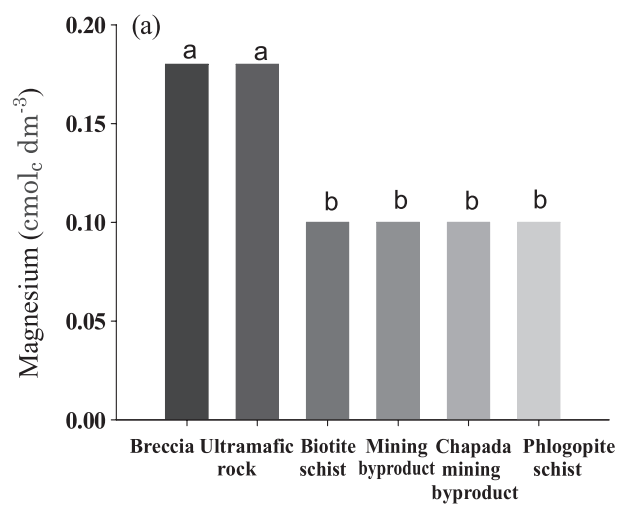

(c)

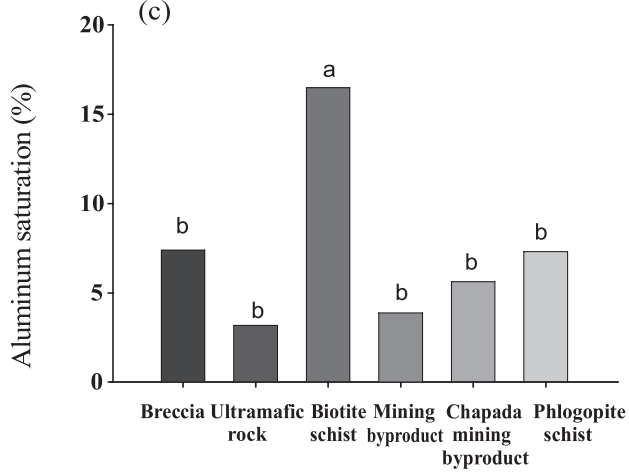

The $\mathrm{Mg}^{2+}$ levels and respective base saturation were influenced by the alternative nutrient sources (Figure 5a,b). The $\mathrm{Mg}^{2+}$ availability (Figure 5a) and $\mathrm{Mg}$ saturation (Figure 5b) were higher after application of breccia and other ultramafic rock. Before applying the alternative fertilizers, the $\mathrm{Mg}^{2+}$ content $\left(0.10 \mathrm{cmol}_{\mathrm{c}} \mathrm{dm}^{-3}\right)$ in the soil was in the class "very low" (CFSEMG, 1999), and after addition of ultramafic rock the availability class changed to "low" $\left(0.18 \mathrm{cmol}_{\mathrm{c}} \mathrm{dm}^{-3}\right)$.

CEC saturation by the element, which was $5 \%$, did not increase to the expected values of $10-20 \%$ and the highest value was obtained with breccia and ultramafic rock at 6.59 and $6.46 \%$, respectively.

The rocks of this study contained the following minerals: phlogopite schist and talc (phlogopite schist); clay-minerals 2:1 (Chapada mining byproduct); biotite schist (biotite); clay-minerals $2: 1$, pyroxenes, feldspars and olivine (ultramafic rock); and feldspars and phlogopite schist (breccia). These are potential $\mathrm{Mg}$ sources that may become available after reaction in soils (Resende et al., 2007; Meurer 2006).

When ground basalt and olivine were used at rates of $0.0 ; 2.5 ; 5.0 ; 12.5 ; 25.0$; and $50.0 \mathrm{~g} \mathrm{~kg}^{-1}$, corresponding to $0,5,10,25,50$, and $100 \mathrm{t} \mathrm{ha}^{-1}$, at $<0.074 \mathrm{~mm}$ particles, in two soils, incubated
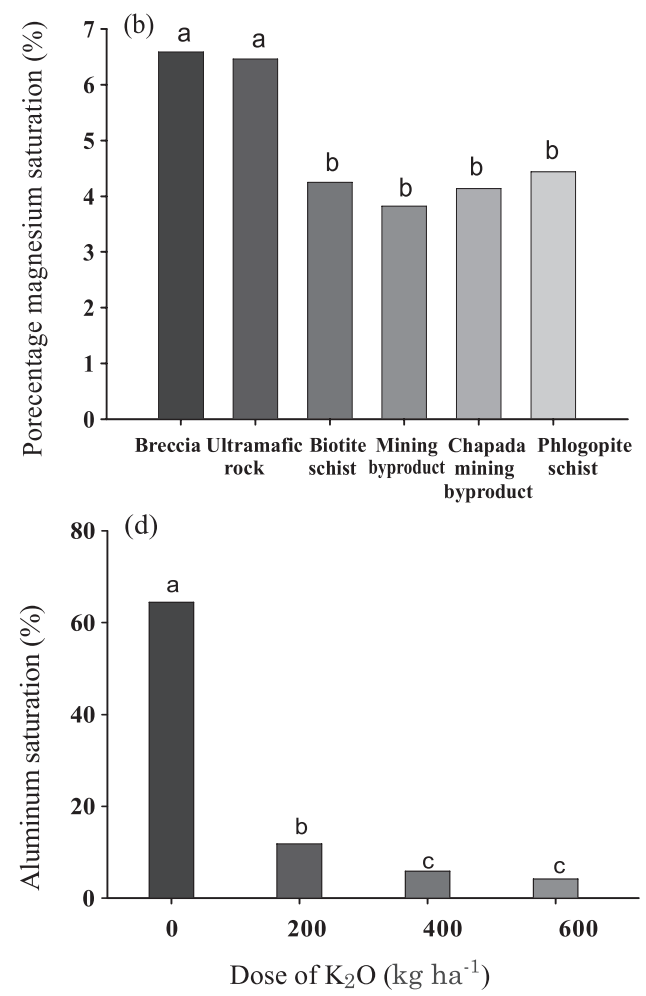

Figure 5. Soil Mg availability (a) and saturation (b), Al saturation (c) as related to ultramafic rock, biotite schist, mining byproduct, Chapada mining byproduct, and phlogopite schist, with the respective fertilizer rate. Al saturation (d) as related to $\mathrm{K}_{2} \mathrm{O}$ levels (average of alternative sources). 
at different periods, there was a considerable increment of available $\mathrm{Mg}^{2+}$ (Escosteguy \& Klant, 1998). Still the levels were also lower than expected for this study.

$\mathrm{Al}$ saturation dropped considerably as a result of fertilizer sources and rates (Figure 5c,d). Biotite schist promoted the least reduction in $\mathrm{Al}$ saturation of all ground rocks (Figure 5c). Biotite schist led to a small increase in $\mathrm{pH}$ (Figure 2a) and had low ECC factors that contributed to a change in $\mathrm{Al}$ saturation in comparison with the other silicate rocks.

Available P (Mehlich-1) in soil increased with silicate rock application (Figure 6a). Highest $\mathrm{P}$ levels were released from ultramafic rock, ranging from $0.9 \mathrm{mg} \mathrm{dm}^{-3}$ (very low) in undisturbed soil to $12.77 \mathrm{mg} \mathrm{dm}^{-3}$ (medium); (CFSEMG, 1999) after incubation for 100 days.

In addition to $\mathrm{K}^{+}$, ultramafic rock also contributed to the increase in available $\mathrm{P}$ in a dystrophic Yellow Latosol (Oxisol) (Ribeiro et al., 2010). The high availability was explained by the naturally P-rich compounds in mafic rocks (Turekian \& Wedepohl, 1962); as they react in soils, $\mathrm{P}$ is released, contributing to offset deficiencies (Table 1).

Mining byproduct was the fertilizer that most released $\mathrm{Zn}^{2+}$, while the other nutrient sources released low amounts of the element into the soil (Figure 6b). The $\mathrm{Zn}$ contribution to the soil was as follows (in descending order): mining byproduct $>$ Chapada mining byproduct $=$ ultramafic rock $=$ breccia $=$ phlogopite schist $=$ biotite .

The total $\mathrm{Zn}^{2+}\left(124 \mathrm{mg} \mathrm{kg}^{-1}\right)$ level in the Chapada byproduct was lower than in biotite schist (151 mg kg-1) and phlogopite schist (149 $\left.\mathrm{mg} \mathrm{kg}^{-1}\right)$; (Table 1), although it released higher levels into the soil. Since the ground rocks were applied on the basis of their respective $\mathrm{K}_{2} \mathrm{O}$ content, the amount of phlogopite schist was lower than in the byproduct and biotite schist, partly explaining these differences. Biotite contains greater $\mathrm{Zn}^{2+}$ quantities and was applied at higher levels than the Chapada byproduct, although releasing less $\mathrm{Zn}^{2+}$ to the soil. This could be related to $\mathrm{Zn}^{2+}$ sorption to amorphous and 2:1 type soil particles, present in the Chapada byproduct (Figure 3). As already pointed out (Figure 1a), the $\mathrm{pH}$ was influenced by the rock powder in the soil; its increase results in higher $\mathrm{pH}$-dependent negative charges, increasing $\mathrm{Zn}^{2+}$ retention.

Zinc is present in various basic and acidic rocks, due to isomorphic $\mathrm{Mg}$ substitution by $\mathrm{Zn}$, common in silicate types. The element also appears in primary minerals, e.g., in olivine, in ultramafic rock, hornblende, augite, biotite, and magnetite. Other minerals containing $\mathrm{Zn}$ are sulphides (spharelite), carbonates, and phosphates (Souza \& Ferreira, 1991; Raij, 1991).

The $\mathrm{Zn}^{2+}$ soil levels were found to be above the critical level $\left(>1.2 \mathrm{mg} \mathrm{dm}^{-3}\right)$ in the treatments that received mining byproduct, at all $\mathrm{K}_{2} \mathrm{O}$ rates.

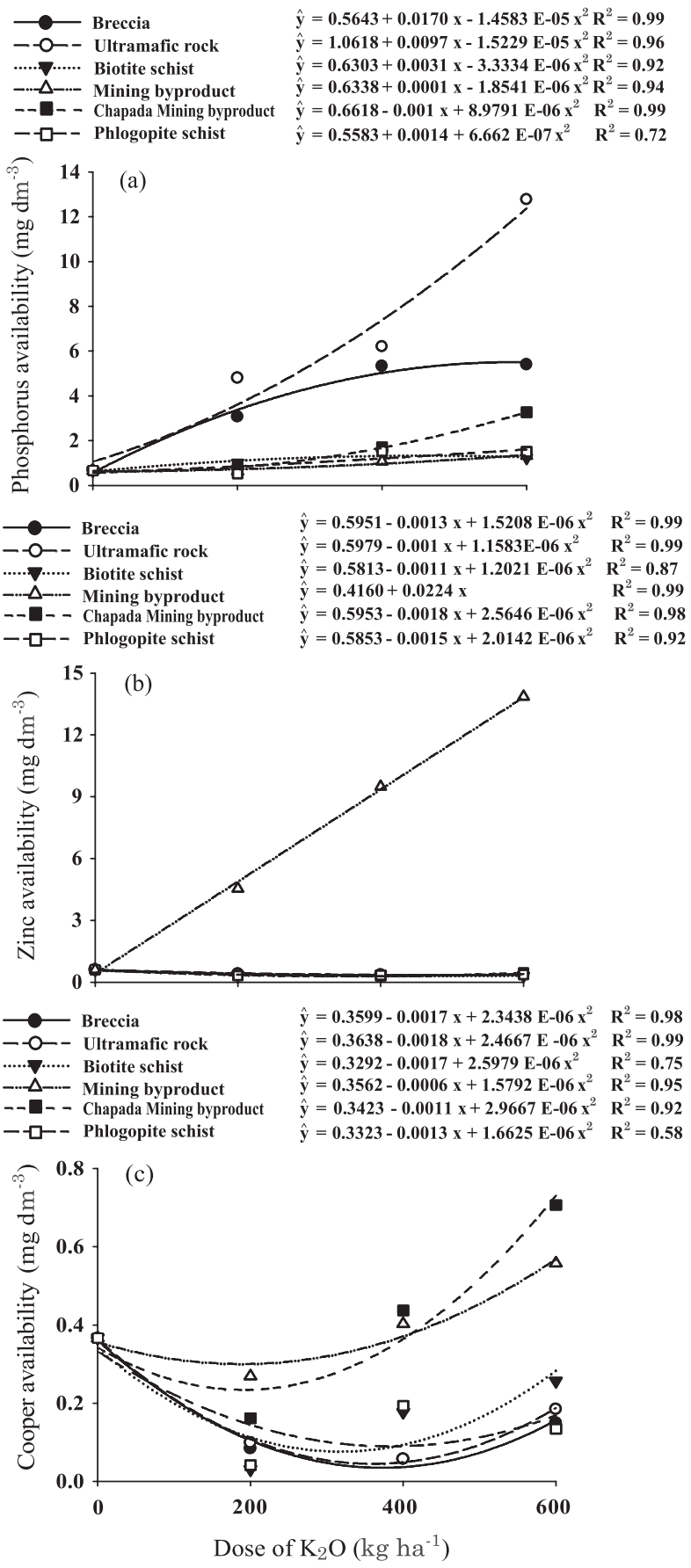

Figure 6. Available soil phosphorus (Mehlich-1) (a), zinc (b) and copper (c), extracted by DTPA solution, at variable rates of breccia, ultramafic rock, biotite schist, mining byproduct, Chapada mining byproduct and phlogopite schist. 
Copper release from to the soil was intensive when Chapada byproduct and mining byproduct were applied (Figure 6c), explained by their high $\mathrm{Cu}$ contents and $\mathrm{Cu}$ amounts applied to the soil (Tables 1,3). In general, $\mathrm{Cu}$ increase was proportional to the applied rock rates. The lowest $\mathrm{Cu}$ availability $\left(0.0307 \mathrm{mg} \mathrm{dm}^{-3}\right)$ was recorded after $200 \mathrm{~kg} \mathrm{ha}^{-1} \mathrm{~K}_{2} \mathrm{O}$ in biotite schist, and the highest level after Chapada byproduct application, at $600 \mathrm{~kg} \mathrm{ha}^{-1} \mathrm{~K}_{2} \mathrm{O}\left(0.7067 \mathrm{mg} \mathrm{dm}^{-3}\right)$.

The $\mathrm{pH}$ increase related to rock powder application (Figure 1a) increases $\mathrm{Zn}^{2+}$ and $\mathrm{Cu}^{2+}$ adsorption in soil, possibly explaining the lower $\mathrm{Cu}^{2+}$ extraction in most treatments compared to the control. In general, complexing with soil organic matter occurs in the descending order: $\mathrm{Cu}>\mathrm{Zn}>$ Mn (Abreu et al., 2007).

The mining byproduct has a higher $\mathrm{Cu}^{2+}$ content than the Chapada byproduct, but was applied at lower rates (Tables 1,3). This could be the cause for the higher $\mathrm{Cu}^{2+}$ release.

Finally, no significant changes in $\mathrm{Ni}$ were observed in soil interaction with the $\mathrm{K}_{2} \mathrm{O}$ rates, ascribed to the naturally low Ni levels in the silicate rocks used here.

\section{CONCLUSIONS}

1. The varied chemical composition of the six silicate rocks tested in this study recommends them as alternative lime sources, while additionally supplying $\mathrm{K}$ and other nutrients.

2. The application of rock powder alters the soil $\mathrm{pH}$, nutrient and $\mathrm{Na}$ availability and other chemical properties.

3. High rates of ultramafic rock and Chapada mining byproduct cause a $\mathrm{pH}$ increase and ionic imbalance with high $\mathrm{Na}$ saturation CEC of with high $\mathrm{Na}$ saturation.

4. The mining byproduct raises the levels of available $\mathrm{K}$, and increases available $\mathrm{Zn}$ and $\mathrm{Cu}$ considerably. Cooper also increases when mining byproducts are applied to the soil.

\section{ACKNOWLEDGEMENTS}

This study was financially supported by the Brazilian Council for Scientific and Technological Development $(\mathrm{CNPq})$ and Minas Gerais Research Support Foundation (FAPEMIG).

\section{LITERATURE CITED}

ABREU, C.A.; LOPES, A.S. \& SANTOS, G.C.G. Micronutrientes. In: NOVAIS, R.F.; ALVAREZ V., V.H.; BARROS, N.F.; FONTES, R.L.F.; CANTARUTTI, R.B. \& NEVES, J.C.L., eds. Fertilidade do solo. Viçosa, MG, Sociedade Brasileira de Ciência do Solo, 2007. p.645-736.

ASSOCIAÇÃO NACIONAL PARA DIFUSÃO DE ADUBOS ANDA. Anuário estatístico do setor de fertilizantes. São Paulo, 1986/2011.

ANDRADE, L.R.M.; MARTINS, E.S. \& MENDES, I.C. Avaliação de uma rocha ígnea como corretivo de acidez e disponibilização de nutrientes para as plantas. Planaltina, Embrapa Cerrados, 2002. 19p. (Boletim de Pesquisa e Desenvolvimento, 57)

AZZONE, R.G. \& RUBERTI, E. Evolução composicional dos filossilicatos no perfil intempérico do complexo ultramáfico Alcalino-carbonatítico de Catalão I (GO). Geol. USP, Série Científica, 10:23-43, 2010.

BAKKEN, A.K.; GAUTNEB, H.; SVEISTRUP, T. \& MYHR, K. Crushed rocks and mine tailings applied as K fertilizers on grassland. Nutr. Cycl. Agroecosyst., 56:53-57, 2000.

BIGHAM, J.M.; BHATTI, T.M.; VUORINEN, A. \& TUOVINEN, O.H. Dissolution and structural alteration of phlogopite mediated by proton attack and bacterial oxidation of ferrous iron. Hydrometallurgy, 59:301-309, 2001.

BRADY, N.C. \& WEIL, R. R. The nature and properties of soils. 13.ed. Upper Saddle River, Pearson Education, 2002. 960p.

BRASIL. Ministério da Agricultura. Manual de métodos analíticos oficiais para fertilizantes minerais, orgânicos, organominerais e corretivos. Brasília, 2007.

BROWN, G.; NEWMAN, A.C.D.; RAYNER, J.H. \& WEIR, A.H. The structures and chemistry of soil clay minerals. In: GREENLAND, D.J. \& HAYES, M.H., ed. The chemistry of soil constituents. Chichester, Jonh Wiley \& Sons, 1978. p.29-178.

COMISSÃO DE FERTILIDADE DO SOLO DO ESTADO DE MINAS GERAIS - CFSEMG. Girassol. In: RIBEIRO, A.C.; GUIMARÃES, P.T.G. \& ALVAREZ V., V.H., eds. Recomendações para o uso de corretivos e fertilizantes em Minas Gerais, $5^{\text {a }}$ Aproximação. Viçosa, MG, 1999. 310p.

CURI, N.; KÄMPF, N. \& MARQUES, J.J. Mineralogia e formas de potássio em solos do Brasil. In: YAMADA, T. \& ROBERTS, T.L., eds. Potássio na agricultura brasileira. Piracicaba, Associação Brasileira para a Pesquisa da Potassa e do Fosfato, 2005. p.71-92.

DEER, W.A.; HOWIE R.A. \& ZUSSMAN, J. Rock-forming minerals - Sheet silicates. London, Longman, 1962. v.3. 270p.

ESCOSTEGUY, P.A.V. \& KLANT, E. Basalto moído como fonte de nutrientes. R. Bras. Ci. Solo, 22:11-20, 1998.

FERREIRA, D.F. SISVAR: Um programa para análises e ensino de estatística. R. Symposium, 6:36-41, 2008. 
FYFE, W.S.; LEONARDOS, O.H. \& THEODORO, S.H. The use of rocks to improve family agriculture in Brazil. An. Acad. Bras. Ci., 78:721-730, 2006.

HARLEY, A.D. \& GILKES, R.J. Factors influencing the release of plant nutrient elements from silicate rock powders: A geochemical overview. Nutr. Cycl. Agroecosyst., 56:11-36, 2000 .

HILSINGER, P.; BOLLAND, M.D.A. \& GILKES, R.J. Silicate rock powder: Effect on selected chemical properties of a range of soils from Western Australia and on plant growth as assessed in a glasshouse experiment. Nutr. Cycl. Agroecosyst., 45:69-79, 1996.

LEONARDOS, O.H.; ULBRICH, M.N.C. \& GASPAR, J.C. The Mata da Corda volcanic rocks. 5th In: INTERNATIONAL KIMBERLITE CONFERENCE, 5., Field Guidebook, CPRM, 3/91, 1991. p.65-72.

LEONARDOS, O.H. \& THEODORO, S.H. Fertilizing tropical soils for sustainable development. In: FORMOSO, M.L.L. \& CERRI, C.C., orgs. INTERNATIONAL WORKSHOP ON TROPICAL SOILS, Rio de Janeiro, 1999. Proceedings... Rio de Janeiro, Academia Brasileira de Ciências 1999. p.143-153.

LEONARDOS, O.H.; THEODORO, S.H \& ASSAD, M.L. Remineralization for sustainable agriculture: A tropical perspective from a Brazilian viewpoint. Nutr. Cycling Agroecosyst.. 56:3-9, 2000.

LOPES, A.S. Manual internacional de fertilidade do solo. Tradução e adaptação. 2.ed. Piracicaba, Potafos, 1998. 177p.

MANNING, D.A.C. Mineral sources of potassium for plant nutrition: A review. Agron. Sustainable Develop., 30:81294, 2010.

MEURER, E.J. ed. Fundamentos de química do solo. 3.ed. Porto Alegre, Evangraf, 2006. 285p.

MOREIRA, A.; CASTRO, C.; OLIVEIRA, F.A.; SALINET, L.H. \& SFREDO, G.J. Efeito residual de rochas brasileiras como fertilizantes e corretivos da acidez do solo. Esp. Geog., 9:163-177, 2006.

NOGUEIRA, N.O.; TOMAZ, M.A.; ANDRADE, F.V.; REIS, E.F. \& BRINATE, S.V.B. Influência da aplicação de dois resíduos industriais nas propriedades químicas de dois solos cultivados com café arábica. Ci. Agron., 43:11-21, 2012.

OLIVEIRA, F.A.; CASTRO, C.; MOREIRA, A. \& ROSA, J.L. Eficiência da adubação residual com rochas brasileiras para a cultura da soja. Esp. Geog., 9:231-246, 2006.

OLIVEIRA, L.A.M. DNPM - Departamento Nacional de Produção Mineral. Sumário mineral. 2008. Disponíble in: <http:// www.dnpm.gov.br> Accessed: 12 Nov, 2010.

RAIJ, B. van. Geoquímica de micronutrientes. In: FERREIRA, M.E. \& CRUZ, M.C.P., eds. Micronutrientes na agricultura. Piracicaba, POTAFOS/CNPq, 1991. p.99-111.
RESENDE. A.V.; MARTINS, E.S.; SENA, M.C.; MACHADO, C.T.T.; KINPARA, D.I. \& OLIVEIRA FILHO, E.C. Suprimento de potássio e pesquisa de uso de rochas "in natura" na agricultura brasileira. Esp. Geog., 9:17-40, 2006.

RESENDE. M.; CURI, N.; REZENDE, S.B. \& CORRÊA, G.F. Pedologia: Bases para distinção de ambientes. Lavras, Universidade Federal de Lavras, 2007. 322p.

RIBEIRO, L.S.; SANTOS, A.R.; SOUZA, L.F.S. \& SOUZA, J.L. Rochas silicáticas portadoras de potássio como fontes do nutriente para as plantas. R. Bras. Ci. Solo., 34:891-897, 2010.

RICHARDS, L.A. Diagnosis and improvement of saline and alkali soils. Washington, US Department Agriculture, 1954. 160p. (USDA Agricultural Handbook, 60)

STANFORD, R.A.; LIMA, R.A.; LIRA, M.A. \& SANTOS. C.R.S. Effectiveness of phosphate and potash rocks with Acidithiobacillus on sugarcane yield and their effects on soil chemical properties. World J. Microbiol. Biotechnol., 24:2061-2066, 2008.

SOUZA, E.C.A. \& FERREIRA, M.E. Micronutrientes no solo: Zinco. In: FERREIRA, M.E. \& CRUZ, M.C.P., eds. Micronutrientes na agricultura. Piracicaba, POTAFOS/ CNPq, 1991. p.219-242.

SOUZA, M.A.S.; SILVA. D.R.G.; ÁVILA, F.W.; FAQUIN, V.; OLIVEIRA, G.C. \& BASTOS, C.E.A. Previous cultivation of palisade grass and soil correctives: Influence on growth and yield of soybean cultivated under various soil compaction levels. Ci. Agrotec., 35:1132-1140, 2011.

THEODORO, S.H. \& LEONARDOS, O.H. Sustainable farming with native rocks: The transition without revolution. An. Acad. Bras. Ci., 78:715-720, 2006.

TUREKIAN, K.K. \& WEDEPOHL, K.H. Distribution of the elements in some units of the earth. Geol. Soc. Am. B., $72: 175-192,1962$.

UNITED STATES ENVIRONMENTAL PROTECTIONAGENCY - USEPA. Method 3052. 1996. Disponível em: <http://www. epa.gov/SW-846/pdfs/3050b.pdf>. Accessed 21 Sept, 2011.

van STRAATEN, P. Agrogeology - The use of rocks for crops. Cambridge, Enviroquest, 2007. 440p.

WANG, J.G.; ZHANG, F.S.; CAO, Y.P. \& ZHANG, X.L. Effect of plant types on release of mineral potassium from gneiss. Nutr. Cycl. Agroecosyst., 65:115-127, 2000.

WILPERT, K.V. \& LUKES, M. Ecochemical effects of phonolite rock powder, dolomite and potassium sulfate in a spruce stand on an acidified glacial loam. Nutr. Cycl. Agroecosyst., 56:37-44, 2000.

WILSON, M.J. Weathering of the primary rock-forming minerals: Processes, products and rates. Clay Miner., 39:233-236, 2004. 